\title{
Correction to: Post-marketing withdrawal of 462 medicinal products because of adverse drug reactions: a systematic review of the world literature
}

Igho J. Onakpoya*, Carl J. Heneghan and Jeffrey K. Aronson

\section{Correction to: BMC Med}

https://doi.org/10.1186/s12916-016-0553-2

The original article [1] contains a minor error whereby the dates for year of first launch and year of first report of adverse reaction for iophendylate in e-Appendix Table 1 are mistakenly presented as 1946 and 1975 respectively. The actual dates for these are 1944 and 1945 respectively. The correct version of e-Appendix Table 1 is shown in the Additional file 1. This Table should be taken into account over the version of e-Appendix Table 1 as shown in the original article [1].

\section{Additional file}

Additional file 1: E-appendix Table 1. List of medicinal products

withdrawn because of adverse drug reactions. (DOCX $157 \mathrm{~kb}$ )

Received: 22 February 2019 Accepted: 22 February 2019

Published online: 02 March 2019

\section{Reference}

1. Onakpoya IJ, Heneghan CJ, Aronson JK. Post-marketing withdrawal of 462 medicinal products because of adverse drug reactions: a systematic review of the world literature. BMC Med. 2016;14:10 https://doi.org/10.1186/s12916016-0553-2.

\footnotetext{
* Correspondence: igho.onakpoya@phc.ox.ac.uk

Centre for Evidence-based Medicine, Nuffield Department of Primary Care

Health Sciences, University of Oxford, New Radcliffe House, Radcliffe

Observatory Quarter, Oxford OX2 6GG, UK
}

C The Author(s). 2019 Open Access This article is distributed under the terms of the Creative Commons Attribution 4.0 International License (http://creativecommons.org/licenses/by/4.0/), which permits unrestricted use, distribution, and reproduction in any medium, provided you give appropriate credit to the original author(s) and the source, provide a link to the Creative Commons license, and indicate if changes were made. The Creative Commons Public Domain Dedication waiver (http://creativecommons.org/publicdomain/zero/1.0/) applies to the data made available in this article, unless otherwise stated. 